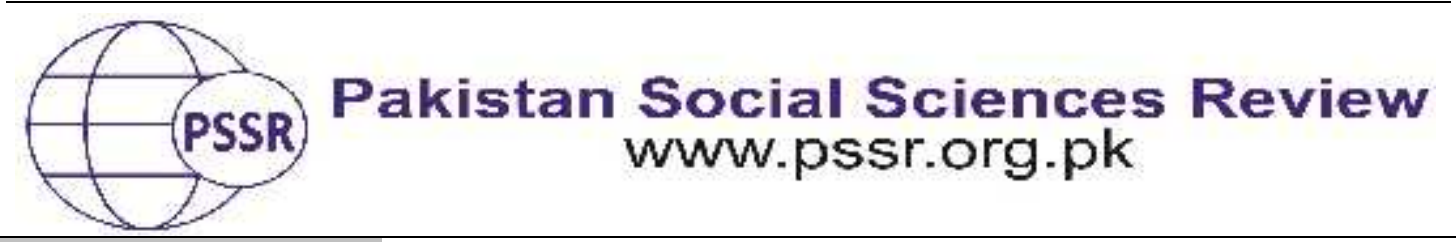

RESEARCH PAPER

\title{
Portrayal of Pakistan in USA Print Media
}

\author{
Hassan Naseer ${ }^{1}$ Prof. Dr. Abdul Wajid Khan ${ }^{2}$
}

1. Ph. D Scholar, Department of Media Studies, The Islamia University Bahawalpur, Punjab, Pakistan

2. Professor, Department of Media Studies, The Islamia University Bahawalpur, Punjab, Pakistan

\begin{tabular}{|c|c|}
\hline & \\
\hline & \multirow{15}{*}{$\begin{array}{l}\text { The study analyzes and investigates the "Portrayal of Pakistan in } \\
\text { US dailies" through content analysis of Washington Post and The } \\
\text { New York Times. For it researcher analyzed all the editorials } \\
\text { published from September } 2001 \text { to } 2018 \text {. Data was analyzed in the } \\
\text { light of framing theory. The universe of the study is New York } \\
\text { Times and Washington Post, and researcher took editorials as } \\
\text { sample for research. The researcher conducts the content analysis } \\
\text { of } 123 \text { editorials regarding Pakistan in both dailies. After data } \\
\text { collection the study investigated data according to the defined } \\
\text { categories and subcategories. The study performed statistical } \\
\text { analysis by using statistical procedures and presented results in } \\
\text { graphical form. The findings revealed that the majority of } \\
\text { editorials regarding Pakistan are unfavorable and Pakistan do } \\
\text { not have positive image in US mainstream print media. Both } \\
\text { dailies gave coverage to Pakistan according to the US interest } \\
\text { with Pakistan. The statistical test chi-square was applied for } \\
\text { testing the hypothesis. It is confirmed that both dailies represent } \\
\text { Pakistan image unfavorably after } 9 / 11 \text { incident and they are } \\
\text { extremely prejudice about Pakistan. }\end{array}$} \\
\hline & \\
\hline & \\
\hline & \\
\hline & \\
\hline Dec & \\
\hline & \\
\hline & \\
\hline & \\
\hline & \\
\hline & \\
\hline & \\
\hline & \\
\hline & \\
\hline & \\
\hline
\end{tabular}

\section{Introduction}

Media has established its utility in this era. Media played important role in communicating with the society that what occur within the world. Now a day, people are totally dependent on the media to acquire information about what is happening in the world and in their surroundings (Happer, 2013).

Entman and Ballantyne (1993) stated it is not about the mediator of information but in addition it alters the rationalization of persons about the world. It selects some aspects of an event to highlight the importance of an issue or event to its audience in order to portray it, enlighten its grounds and accentuate on its moral results. Furthermore media educate and inform people with real facts about public 
affairs. But most importantly, media educate the people about how much important it ought to put on one issue in comparison of another (Mccombs, 1972).

Jones (2006) highlights the role of newspaper. Daily papers facet a noteworthy toil by giving about daily narrative of happenings, helping as a political limb and encourage the freedom of expression. In comparison of newspapers, no other source is as inclusive which covers the everyday existence or as wide in its level of plausible substance. Shabbir et al. (2014) argued that portrays of any nation by any other nation contains a far above the ground importance within a globe. With the help of these pictures one can easily evaluate the association of countries.

$\mathrm{Yu}$ and Riffle described in their studies that U.S media display the picture of remote nations on the sake of its nationwide interests and further nations rank. U.S and Pakistan came closer after 9/11 catastrophe and Pakistan joined as a partner in "war on terror" but regardless of Pakistan all endeavors against psychological warfare America never recognize contribution of Pakistan in war on terror. Especially U.S media depict Pakistan in a pessimistic way and portraying Pakistan compatible to U.S government interests. In addition, its approach towards Pakistan has been modifying according to their own concerns (Shabir et al, 2014).

\section{Rationale of selecting Print media}

Print media envelops mass communication through printed objects. It consists of daily papers, glossy magazines, pamphlets and catalogs, house magazines, journals or reports, candidate mailers, flyers or handouts, bulletins, press releases and manuscripts (Houda, 2018).

It established itself as the most valid and solid source of information. Due to its validity and authenticity print media has no comparison with other mediums of communication. On the one hand, the researchers have chosen newspapers due to its distinction, decency, precautions, availability and validity and on the other hand due to the powerful effects of print media as readers become more enlighten about topic because print media make wider the skyline of mind and lead to attain the exact purpose of reading (Dominick, 1993).

\section{Rationale for selecting Newspapers}

Jones (2006) said that newspapers can be used to establish validity. He said for it, they have to complete subjective and ruined, or if they can in particular be a symbol of the community judgment.

"Daily papers elated the position of the foremost favored medium to reach a more extensive gathering of people until electronic communication raised on the media scene" (Houda, 2018). Jones (2006) argued that newspapers can be used to decide legitimacy; there is some chance that they are pitifully one sided and corrupted, or they can exactly symbolize the public judgments. The researcher decided to select two U.S dailies The Washington Post and The New York Times to 
investigate the overall depiction of Pakistan as these newspapers are considered more prominent in other U.S dailies and have higher circulation.

\section{Rationale for selecting Pak-U.S relation}

Ahmed (2016) stated that media specialists and policy makers are always interested to investigate Pak-U.S relations even there are many ups and downs in it but their relations have great importance with in the financial, social defense, political and instructive framework of Pakistan. According to Hussain (2016), now a day, the major leading authority is no doubt U.S. There is great significance to read out the relations of U.S with other nation (especially with Pakistan in South and West Asia is a well known subject of international politics) and U.S foreign policy. With the above discussion it is established that this research will explore Pak-U.S relations and this research will also dig out the true nature of relationship between both countries. This research is also an attempt to locate the internal and external forces which establish the association among the both countries especially after 9/11 disaster.

\section{Rationale for selecting Time Period}

Researcher selected the timeline from 9/11 to 2019. As historically Pak-U.S relation has never been consistent. This relation has many ups and downs in different phases. So this study aims to dig out how U.S dailies portrayed Pakistan in different era's both in dictatorship and democracy. It was because of convergence and dissimilarity of national interface that kept on exchanging both countries from companionship to resistance (Hussain, 2016). This is the reason; the time frame is selected from 9/11 to 2019 to focus on U.S dailies that how they depict Pakistan.

\section{Hypotheses}

H: It is more likely that Washington Post and The New York Times portray Pakistani image unfavorable after 9/11 incident.

H: It is more likely that Washington Post and The New York Times portray Pakistani image positively after $9 / 11$ incident.

\section{Literature Review}

Rationale behind composing literature review in any study is to give a theoretical foundation to research. It also helps researchers in clarifying his thoughts and helps to select research methodology. It helps to seek out the current development on the under observation phenomena. It also gives a dilapidated synopsis of the offered subject from ahead of time bring out studies about a particular subject (Baker, 2016). 
Several studies (Hallin \& Gitlin, 1993; Hackett \& Zhao, 1994 ; Khan, 2008; Lee, 2004; Noshina, 2007; Noshina \& Hanan, 2014; Ryan, 2004; Safdar., Budiman., \& Norish, 2014; Scheuer, 2008; Shabbir,2011; Siraj,2006) have enfolded up that American media particularly during clash, war and military operations do not exhibit the entire picture of reality, whereas it favor U.S. policies and overlook alternative, as reunion, peace progression and discussion with evidences and arguments. The basic focus of mass media analysis concerning to the World War I and II was that how government utilize their respective media (TV, radio, films, newspapers, etc.) for monitoring and surveillance of the information and sometimes backing propaganda for their specific national interest (Ishaq et al. 2017). Various media researches on conflicts, wars and military operations affirmed that sometimes media work under government pressures when military operations going on (Bui, 2012).

Jamil (2008) said that unfavorable picture of Pakistan is expanding worldwide rather than to bring real or to highlights positive viewpoints of Pakistani country. Jamil spotted, that the picture of Pakistan is coined with terrorism after the incident of 9/11. Mushraff protected and improved universal picture of Pakistan as a nation after 9/11 (Khan, 2009).

In 2016 a study conducted only to seek out the character and source of unfavorable opinions regarding Pakistan. In it, members of Foreign Service programmed at Oxford University were inquired 'what three things come to mind once you listen about Pakistan?' Mostly respondents cited Islam, Terrorism, atomic weapons, security and Taliban. Loaning encourages people to make their opinion about Pakistan as a militarized nation included with Islamic radicalism (Cheema, 2016).

Shabir and Iqbal (2010) conducted a study to seek how U.S print media is depicting Pakistan. Editorials of the two U.S dailies The Guardian and The Daily Telegraph, timeframe from March 2007 to March 2008 was selected to inspect. Researcher came out with findings that influential class' dishonest perform were argue which included dishonesty by the political pioneers, dishonors in cricket etc. Both the dailies appear to inspect the issue with scarcely any distinct peculiarity.

In another study, researcher examines the depiction of Pakistan in the two U.S magazines i.e. Newsweek and Time. Total 128 articles of both magazines were inspected. After the inspection, it was found that both magazines depict unfavorable picture of Pakistan in their news magazines (Ali \& Saleem, 2010).

\section{Theoretical Framework}

The concept of framing will be used as the theoretical foundations to justify the research questions. Framing theory will be applied in this research to explore in what way The New York Times and The Washington Post from United States depict Pakistan from 9/11 too2019. Many and several other scholars used Framing theory 
while analyzing the coverage of media substance during the crash, fight, armed operations and battle (Bui, 2012; Ishaq et al., 2017; Lee, 2004; Rahman \& Eijaz, 2014).

\section{Framing Theory}

Framing theory is selected as umbrella to the research study. Significant reason behind selecting framing theory is that with the help of it one can see an issue from an hodgepodge of viewpoints. It also helps in interpretation of having few suggestions for different qualities or contemplations. It helps the researcher to allude the whole research procedure which helps in making up a specific conceptualization regarding under observed phenomena or alter the opinion of researcher regarding that issue (Chong \& Druckman, 2007). According to this concept, framing can be described as a process in which a few aspects of reality are selected so the purpose is briefed by giving well known anxiety or implication (Ardevol-Arebu, 2015). Etman gave further comprehension of it by adding it, chose the few parts of reality and manage them gradually in a communicating to prop up the concern definition, elemental paraphrase, principled appraisal and management insinuation. The use of framing in news can influence in this way that how beneficiaries of the news come to comprehend these occasions (Scheufele, 1999).

\section{Material and Methods}

Research methodology is a technique to employ to comprehend any research phenomena. One can say it as a logical set of procedure to come to know how research work is done scientifically. It gives proficient and methodical work draft and depicts the basic strategies for accomplishment of basic research goals. Research methodology is similar to an instrument utilized by the researcher to quantify the activities of the research work (Bist, 2014).

This study, through qualitative analysis examined; the editorials of two American dailies, The Washington Post and New York Times. Editorials regarding portrayal of Pakistan from 9/11 to 2019 are selected as sample for the study. This specific time period is significant due to the reason that the two USA's policies about Pakistan in the time of peace and war can be researched. It has been generally perceived that after the 9/11, Afghanistan is/was capable of posing danger to the West and USA as portrayed by the international media. Similarly, American foreign policy objectives and trends linked to Pakistan and Afghanistan were also modified and revived in the wake of end of cold war era. Subsequently, the western media extensively focused the Islamic world after the incident of 9/11. And now America and NATO countries realize their mistakes and struggling for peace through negotiation. Hence, this specific era (9/11 t0 2019) has been selected for the study. A news item (editorial) will be considered as a unit of coding, whereas each paragraph on news item will be considered as unit of analysis. 


\section{Research Design}

A research design helps to understand the action taken by the researcher to collect the relevant data and to investigate the information in a way that expects by coalesce connotation to the research rationale with economy and method. Research design can be said a preplanned activity to conduct research a phenomena under observation (Akhtar, 2016).

The research study will obtain by the help of Content Analysis to get required data from both U.S dailies that will help to deduce the final result. Besides this, it is the cram of the content with orientation to the implications, agenda and objectives enclosed in communication (Prasad, 2008).

\section{Content analysis}

Content analysis is a systematic way to conduct any research. It is an empirical way to explore your research goals. It is a common practice for social scientists to use it for their researches. It is a research procedure in which researcher can make its data compatible and then can compare it with other methods of research. One can easily compare messages whether verbal or non verbal, analysis of different policies and data can be collected, recorded and even can be compared with each other (Kyngs, 2007).

Keeping in view the nature of the issue, the content analysis research method will be employed in order to examine the coverage of Pakistan in two newspapers The New York Time and The Washington Post from United States. A sample of all news stories and editorials from two newspapers The New York Time and The Washington Post from United States related to portrayal of Pakistan will be drawn from table of contents. Similarly, descriptive statistics will be used to analyze our variables.

\section{Universe/Population of the study}

According to Bless and Higson-Smith (1995:85), the universe and population represent the intact faction of units which is the center of attention of the research. Thus, the population can contain all the persons of a country, or of a specific geographical area, or a required ethnic or economic group, it mainly depends on the rationale and treatment of the research.

Those news editorials which are published from 9/11 to 2019 in U.S dailies named New York Times and Washington Post will be taken as universe of the study.

\section{Unit of Analysis}

Unit of analysis is considered as the most important element in any research. Editorials (editorials represent the fair and critical point of view of newspaper and editorial are the most powerful portion of any newspaper) of both U.S dailies 
Washington Post and New York Times are selected as the unit of analysis in this study. One editorial is considered as one unit of analysis.

\section{Categories}

To make categories in research is an attempt to make characterize the work of media. It is a type of casing the words which make able researcher to clarify (Wimmer and Dominick, 2000). There are many advantages to use these categories into suitable research work. In this research, researcher made three categories to find out the direction of contents of U.S dailies. These categories are named as Favorable, Unfavorable and Neutral.

\section{Favorable}

In both U.S dailies New York Times and Washington Post the content of editorial and news stories will categorize as positive, if Sentences which depict development and positive changes in political, economic and social sector promotion of democratic values, peace and harmony, involvement in the accords/ agreement leading to peace and prosperity with Pakistan will be coded as positive. Moreover, the sentences which communicate appreciation of the initiatives taken by the policy makers or rulers of the Muslim countries would be coded with positive slant. Also all the content remains simple, brief and unbiased and if positive sentences would be greater than unfavorable or neutral sentences. Importantly to portray Pakistan as a peaceful state as well as acknowledging efforts of Pakistan regarding 'war on terror' will be considered as positive.

\section{Unfavorable}

The contents of both U.S both dailies will take as unfavorable if Sentences which reflect social strife, natural and human steered deaths and destruction, political instability, catastrophic, chaos and anarchy, shabby living conditions, and political, economic and social intra state and interstate conflicts and deputes, military influence in Pakistan over civil government, depicting Pakistan as a terrorist state, aggressive tone against Pakistan, misleading about women rights in Pakistan, depict Pakistan as inefficient to cope with terrorism and not acknowledging Pakistan efforts on 'war on terror' will be coded as unfavorable sentences. All such sentences which depict criticism of policies in above mentioned sectors as well as derogatory remarks to distort the image of Pakistan would be coded with unfavorable slant.

\section{Neutral}

The content of both dailies will be treated as neutral and balance if the sentences which don't clearly mention emphasis on either positive or unfavorable aspects of the concerned state's economic, political and social life and projecting Pakistan as a moderate state will be coded as neutral sentence. 
Keeping in view the nature and purpose of the research, framing was identified in these articles from the contextual point of view. The finding / results pertaining to over all portrayal of the Pakistan would be elaborated by assigning the keywords/terms on the cumulative basis. Portrayal of the Pakistan is described as favorable, unfavorable or neutral. On account of overall impression of the article, the following rules are devised, for the assessment of the article in the perspective of framing.

The portrayal of Pakistan in Washington Post (9/11 to 2019)

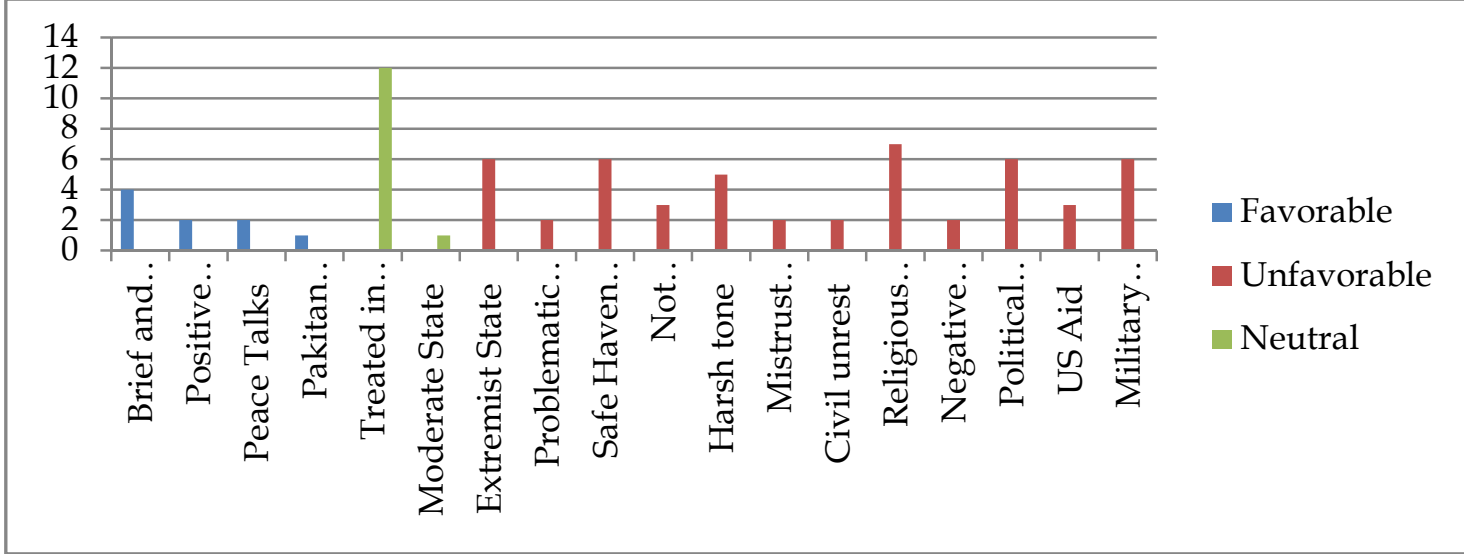

It reflects editorials regarding Pakistan in 19 Years i.e. from 9/11 to 2019 in the Washington Post. There are 9 favorable, 13 neutral and 50 unfavorable editorials in the above mentioned time. Thus the overall frequency is 72 . The findings reveal that the Washington Post is quite prejudiced in Pakistan.

The portrayal of Pakistan in New York Times (9/11 to 2019)

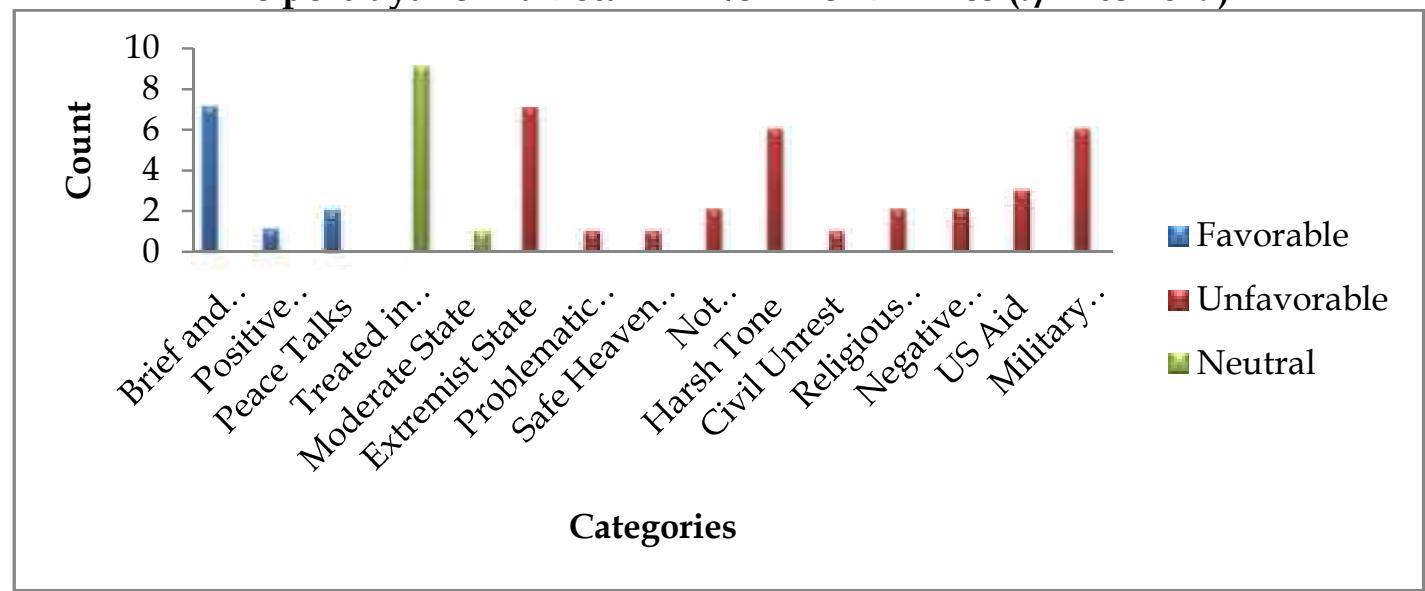

It reflects editorials regarding Pakistan in 19 Years i.e. from 9/11 to 2019 in the New York Times. There are 10 favorable, 9 neutral and 32 unfavorable editorials in the above mentioned time. Thus the overall frequency is 51 . The findings reveal that the New York Times is quite prejudiced in Pakistan. 
The both newspapers published whole editorials on following categories during proposed period of research.

- Brief and Unbiased

- Positive Sentences

- Peace Talk

- Treated in Balanced Way

- Moderate State

- Extremist State

- Problematic Nation

- Safe Heavens for Terrorists

- Not acknowledging Pakistani Efforts

- Harsh Tone

- Civil Unrest

- Religious Intolerance

- Unfavorable Perception of Political leaders

- USA aid

- Military Influence

Both newspapers published 123 editorials in selected time frame. Now we discuss each category. In the category of Brief and Unbiased, Washington Post published 4 positive editorials and New York Times published 7 positive editorials. In the category of Positive sentences, Washington Post published 2 positive editorials and New York Times published 1 positive editorial. In the category of Peace Talks, Washington Post published 2 positive editorials and New York Times also published 2 editorials. In the category of Treated in Balanced Way, Washington Post published 12 neutral editorials and New York Times published 9 neutral editorials. In the category of Moderate State, Washington Post published 1 neutral editorials and New York Times published 1 neutral editorial. In the category of Extremist State, Washington Post published 6 unfavorable editorials and New York Times published 7 unfavorable editorials. In the category of Problematic State, Washington Post published 2 unfavorable editorials and New York Times published 1 unfavorable editorial. In the category of Problematic State, Washington Post published 2 unfavorable editorials and New York Times published 1 unfavorable editorial. In the category of Safe Heavens for Terrorist, Washington Post published 6 unfavorable editorials and New York Times published 1 unfavorable editorial. In the category of not acknowledging efforts, Washington Post published 3 unfavorable editorials and New York Times published 2 unfavorable editorials. In the category of harsh tone, Washington Post published 5 unfavorable editorials and New York Times published 6 unfavorable editorials. In the category of civil unrest, Washington Post published 2 unfavorable editorials and New York Times published 1 unfavorable editorial. In the category of religious intolerance, Washington Post published 7 unfavorable editorials and New York Times published 2 unfavorable editorials. In the category of unfavorable image of political leaders, Washington Post published 2 unfavorable 
editorials and New York Times published 2 unfavorable editorials. In the category of US aid, Washington Post published 3 unfavorable editorials and New York Times published 3 unfavorable editorials. In the category of military influence, Washington Post published 6 unfavorable editorials and New York Times published 6 unfavorable editorials. Both newspapers published $15.44 \%$ positive, $66.67 \%$ unfavorable and $17.68 \%$ neutral editorials. So these results shows that the overall ratio of coverage of both US dailies about Pakistan remained unfavorable and it approved the hypothesis, "It is more likely that Washington Post and The New York Times portray Pakistani image unfavorable after 9/11 incident" is true.

Also according to above discussed results, it is verified by results that the hypothesis, "It is more likely that Washington Post and The New York Times portray Pakistani image positively after 9/11 incident" is not true.

\section{Recommendations}

US print media portrayed Pakistani differently in different eras. As an alley US press started positive coverage of Pakistan but there are main issues portrayed and depicted in unfavorable manner. It is the suggestion from researcher that US print media should portrayal neutral image about the sensitive issues; like state actions against terrorism issues, US aid, relations between both countries and image of political leaders. It is suggested that these issues should be covered on merit and US press should not follow long term strict agenda on these issues. It is suggested that US print media while following foreign policy of US should also observe impartiality. As it is a known fact that US media shaped the world opinion and issues to resolve. In this sense, it should be free and fair and cover all the happenings of world in their true nature. So that the opinion of the world can be make plain and positive about other countries. 


\section{References}

Ahmed, I. (2016). Pakistan USA Relation, Contemporary Challenges and opportunities. https://www.researchgate.net/publication/304462844

Akhtar, S. (2012). Dynamics of USA-Pakistan relations in the post 9/11 period: Hurdles and future prospects. International Journal of Humanities and Social Science, 2(11), 205-213.

Ali, Z., Jan, M., \& Saleem, N. (2013). Portrayal of Pakistan by US leading news magazines. Science International, 25, 4 .

Ardèvol-Abreu, A. (2015). Framing theory in communication research. Origins, development and current situation in Spain. Revista Latina de Comunicación Social, (70), 423-450

Baker, J. D. (2016). The purpose, process, and methods of writing a literature review. AORN journal, 103(3), 265-269.

Bist, R. B. (2014). Research procedure: An introduction. Journal of NELTA Surkhet, 4, 34-40.

Bui, N. (2012). War/ Peace Journalism Approach in Vietnamese Online Media Coverage of South China Sea Dispute. Unpublished MA thesis,Global Journalism, Orebro University.

Cheema, N. (2016). Pakistan's Global Image: Perception and Causes. Asian Affairs Journal Weblog.

Chong, D., \& Druckman, J. N. (2007). Framing theory. Annu. Rev. Polit. Sci., 10, 103126.

Entman, M. L., \& Ballantyne, C. M. (1993). Inflammation in acute coronary syndromes. Circulation, 88(2), 800-803.

Hackett, R. A., \& Zhao, Y. (1994). Challenging a master narrative: Peace protest and opinion/editorial discourse in the US press during the Gulf War. Discourse $\mathcal{E}$ Society, 5(4), 509-541.

Hallin, D. C., \& Gitlin, T. (1993). Agon and ritual: The Gulf War as popular culture and as television drama. Political Communication, 10(4), 411-424.

Happer, C., \& Philo, G. (2013). The role of the media in the construction of public belief and social change. Journal of social and political psychology, 1(1), 321-336.

Hussain, M. (2016). Pak-US relations: An historical overview. Pakistan Journal of History and Culture, 37(2), 61-76. 
Ishaq, N., Saleem, N., Ahamd, H., \& Amber, S. (2017). Covering Us Led Invasion Of Afghanistan: A Comparative Analysis Of The Treatment Of The Economist, Time And The Herald. Journal of the Research Society of Pakistan, 54(2), 249-265

Khan, M. A. (2009). India's sikh militants forming ties with Lashkar-e-Taiba and Pakistani intelligence. Terrorism Monitor, 7(1), 1-4.

Khan, H. (2013). Pakistan's Contribution to global war on terror after 9/11. IPRI Journal, 13(1), 37-56.

Jones, J. P. (2006). A cultural approach to the study of mediated citizenship. Social Semiotics, 16(2), 365-383.

Lee, C.-H. (2004). News Coverage of U.S. War With Iraq: A Comparison of The New York Times, The Arab News, and The Middle East Times, Unpublished PhD thesis. The University of Texas at Austin.

McCombs, M. E. (1972). Mass media in the marketplace. Journalism and Communication Monographs, 24.

Noshina, S. (2007). U.S. Image in Pakistani English dailies Dawn, The Nation and The News with special reference to Pakistan-United States relationship during post cold war era (Unpublished Doctoral Dissertation). Institute of Communication Studies, University of Punjab. Lahore.

Noshina. S, \& Hanan, M. A. (2014). Media and conflict resolution: Towards building a relationship model. Journal of Political Studies, 21(1), 179-198

Prasad, B. D. (2008). Content analysis. Research methods for social work, 5, 1-20.

Rahman, B. H. \& A. Eijaz. (2014). Pakistani Media as an Agent of Conflict or Conflict Resolution: A Case of Lal Masjid in Urdu and English Dailies. Pakistan Vision, 15 (2): 238- 264.

Ryan, M. (2004). Framing the War against Terrorism: US newspaper editorials and military action in Afghanistan. Gazette: The International Journal For Communication Studies, 66(5). 363-382

Safdar, A., Budiman, M. A. \& Hamid, A. B. N. (2014). Media conformity of foreign policy: of war on terror by the British press. J.R.S. P, 51(01).

Scheuer, M. (2009). Marching towards hell America and Islam after Iraq. New York, NY: Free Press.

Scheufele, D. A. (1999). Framing as a theory of media effects. Journal of communication, 49(1), 103-122. 
Shabbir, G., Hassan, A., Madni, A. R., \& Ahmed, N. (2014). War on Terror: Interplay between Press (Daily the Nation \& Daily Times of India) and Governments (Pakistan \& India) Policies. Global Media Journal: Pakistan Edition, 7(1).

Shabir, G., \& Iqbal, Z. (2010). Media Construction of Pakistan's Image: Discourse Analysis of Editorials of the Elite UK Newspapers. China Media Research, 6(3).

Shabir, Ghulam; Ali, Shahzad; Iqbal, Zafar (2011). US Mass Media and Image of Afghanistan: Portrayal of Afghanistan by Newsweek and Time. South Asian Studies. 26 (1): 83-101

Siraj, S. A. (2006). Image of Pakistan in the US Media: Exploring News Framing. Mass Communication, University of Southern Illinois Carbondale, USA. Post Doctorate Dissertation.

Wimmer, R. D., \& Dominick, J. R. (2000). Mass media research: An introduction Wadsworth. Belmont, CA. 